\title{
The effects of Robertsonian fusions on chiasma frequency and distribution in the house mouse (Mus musculus domesticus) from a hybrid zone in northern Scotland
}

\author{
CLAUDIO J. BIDAU*†, MABEL D. GIMÉNEZ†, CHRISTIANNE L. PALMER $\ddagger$ \\ \& JEREMY B. SEARLE \\ $\dagger$ Facultad de Ciencias Exactas, Químicas y Naturales, Universidad Nacional de Misiones, Félix de Azara 1552, 3300 \\ Posadas, Misiones, Argentina and †Department of Biology, University of York, PO Box 373, York YO10 5YW, U.K.
}

\begin{abstract}
Chiasma frequency and distribution were studied in male Mus musculus domesticus from the John O'Groats-standard chromosomal hybrid zone in northern Scotland. Individuals of the John O'Groats race ( $2 n=32$; homozygous for the Robertsonian fusions 4.10, 6.13, 9.12 and 11.14) and the standard race $(2 n=40$, all telocentric), and hybrids with various karyotypes, were examined. Chiasma frequency was significantly negatively correlated with the number of Robertsonian configurations in the meiotic cell. The decrease of chiasma frequency can be attributed to intrachromosomal effects that reduce the number of chiasmata in Robertsonian bivalents (formed in homozygotes for Robertsonian fusions) and trivalents (formed in heterozygotes). However, the reduction is more pronounced in Robertsonian bivalents and is related to a shift of chiasmata to the distal ends of the chromosome arms. A different type of repatterning occurs in trivalents where there is a significant increase in proximal and interstitial chiasmata.
\end{abstract}

Keywords: chiasmata, hybrid zone, meiosis, Mus musculus domesticus, Robertsonian fusion.

\section{Introduction}

Single or multiple Robertsonian ( $\mathrm{Rb}$ ) fusions are involved in evolutionary divergence of many animal and plant species (Capanna, 1982; Baker \& Bickham, 1986; Jones, 1990; Bidau, 1991; King, 1993). It is expected within the framework of several chromosomal speciation models, that hybrids between $\mathrm{Rb}$ divergent populations should show reduced fertility due to the meiotic consequences of fusion heterozygosity, especially the unbalanced segregation of trivalents or higher order multivalents (Baker \& Bickham, 1986; Bidau, 1991; King, 1993; Searle, 1993). Such structural hybrids may be synthesized in the laboratory or found in nature, usually in hybrid zones at the contact of two chromosomal races. Chromosomal hybrid zones involving $\mathrm{Rb}$ differences have been reported for mammals (Searle, 1993) and insects (Barton \& Hewitt, 1981; Bidau \& Tosto, 1991; Bidau, 1991) and there are also $\mathrm{Rb}$ polymorphisms unrelated to hybridization (Bidau, 1990; Nachman, 1992).

*Correspondence. E-mail: cjbidau@fceqyn.unam.edu.ar

(c) 2001 The Genetics Society of Great Britain.
A further factor needs to be considered in relation to $\mathrm{Rb}$ variation. Chromosomal rearrangements can exert effects on recombination, visualized cytologically as changes in chiasma frequency and localization (John, 1983, 1990; Bidau, 1990, 1993). This repatterning of chiasmata may adversely influence orientation and segregation of both normal bivalents (Moens \& Spyropoulos, $1995)$ and the heterozygous chromosome configurations (Mirol \& Bidau, 1992; Bidau \& Martí, 1995) found in hybrids between $\mathrm{Rb}$ chromosomal races. Chiasma repatterning in hybrids could also disrupt coadapted supergenes, thereby potentially reducing fitness in the $F_{2}$ generation (Bidau, 1996 and references therein).

The West European house mouse, Mus musculus domesticus, is a well-known case of $\mathrm{Rb}$ variation in nature (Capanna, 1982; Redi \& Capanna, 1988; Nachman \& Searle, 1995). A number of Rb chromosomal races have been described and several hybrid zones identified involving multiple differences (Searle, 1993). Although many studies have been devoted to chromosome pairing and segregation in a variety of chromosomal conditions in the house mouse (Gropp \& Winking, 1981; Redi \& Capanna, 1988; Searle, 1988, 1993), almost 
nothing is known about the chiasma effects of $\mathrm{Rb}$ fusions in natural populations of this species.

In this paper we analyse chiasma frequency and distribution in male house mice from a hybrid zone between two $\mathrm{Rb}$ chromosomal races that occur in northern Scotland. The John O'Groats race has $2 n=32$ chromosomes and is fixed for fusions $\mathrm{Rb}(4.10)$, $\mathrm{Rb}(6.13), \mathrm{Rb}(9.12)$ and $\mathrm{Rb}(11.14)$. This race forms $\mathrm{a}$ hybrid zone with the standard and widespread $2 n=40$ (all telocentric) race, in the counties of Caithness and Sutherland (Searle, 1991; Searle et al., 1993). In this paper, we describe a differential effect of heterozygous and homozygous $\mathrm{Rb}$ fusions on chiasma frequency and localization in male mice from the John O'Groatsstandard hybrid zone.

\section{Materials and methods}

The 31 male house mice studied in this paper were live-trapped during two field trips (September and
October 1994) from a variety of farms where there was already information on karyotypes (Searle et al., 1993).

Mice were killed by cervical dislocation. In order to identify the karyotype of each individual, metaphase preparations were obtained from a suspension of bone marrow cells exposed to colcemid according to the method of Ford (1966). G-banding followed the method of Seabright (1972). The right testis was used for meiotic air-dried preparations according to the method of Evans et al. (1964); C-banding of meiotic cells followed Sumner's (1972) protocol. Twenty late diakinesis/metaphase I cells were scored per individual. Chiasmata were counted per telocentric chromosome or metacentric chromosome arm and classified by inspection after dividing them in three equal parts, as proximal (P), interstitial (I) or distal (D). The chromosome constitution of the males analysed is shown in Table 1.

\begin{tabular}{|c|c|c|c|c|c|}
\hline Individual No. & $2 n$ & $\mathrm{Rb}(4.10)$ & $\mathrm{Rb}(6.13)$ & $\mathrm{Rb}(9.12)$ & $\mathrm{Rb}(11.14)$ \\
\hline 1001 & 36 & Hom & $\mathrm{St}$ & Hom & $\mathrm{St}$ \\
\hline 1003 & 36 & Hom & St & Hom & St \\
\hline 1004 & 36 & Hom & $\mathrm{St}$ & Hom & St \\
\hline 1005 & 34 & Hom & Hom & Hom & St \\
\hline 1008 & 34 & Hom & Hom & Hom & St \\
\hline 1009 & 32 & Hom & Hom & Hom & Hom \\
\hline 1010 & 33 & Hom & Het & Hom & Hom \\
\hline 1012 & 36 & Hom & Het & Het & St \\
\hline 1013 & 35 & Hom & St & Hom & Het \\
\hline 1014 & 35 & Hom & Het & Hom & St \\
\hline 1015 & 34 & Hom & Het & Hom & Het \\
\hline 1016 & 36 & Hom & St & Het & Het \\
\hline 1017 & 36 & Hom & Hom & St & St \\
\hline 1018 & 36 & Het & St & Het & Hom \\
\hline 1019 & 35 & Hom & Het & Hom & St \\
\hline 1020 & 34 & Hom & St & Hom & Hom \\
\hline 1023 & 34 & Hom & Het & Hom & Het \\
\hline 1024 & 36 & Hom & St & Hom & St \\
\hline 1025 & 33 & Hom & Het & Hom & Hom \\
\hline 1026 & 36 & Hom & St & Hom & St \\
\hline 1027 & 36 & Hom & St & Het & Het \\
\hline 1028 & 35 & Hom & $\mathrm{St}$ & Het & Hom \\
\hline 1035 & 32 & Hom & Hom & Hom & Hom \\
\hline 1036 & 32 & Hom & Hom & Hom & Hom \\
\hline 1038 & 40 & St & St & St & St \\
\hline 1040 & 40 & St & St & St & St \\
\hline 1041 & 40 & St & St & St & St \\
\hline 1042 & 40 & St & St & St & St \\
\hline 1043 & 40 & St & St & St & St \\
\hline 1052 & 40 & St & St & St & St \\
\hline 1053 & 40 & St & St & St & St \\
\hline
\end{tabular}

Table 1 Diploid numbers and status of Robertsonian fusions in individuals of Mus musculus domesticus from the John O'Groats-standard hybrid zone. The individuals belong to the following localities: Thrumster 2 (1001, 1003-1004), Mains of Olrig (1005, 1008-1009), Dunnet 2 (1010), Ratter (1012), Bardnaclavan (1013-1020, 1023-1028), West Canisbay (1035-1037), Crakraig (1038, 1040-1043) and Brora (1052-1053). Grid references for these localities are provided in Searle et al. (1993) except Thrumster 2 (3342/9442), Ratter (3267/9724) and West Canisbay $(3342 / 9718)$

Hom, homozygous metacentric; Het, heterozygous; St, homozygous standard (telocentric). 


\section{Results}

Chiasma frequency and distribution in the standard and John O'Groats races

In all cases the $\mathrm{XY}$ bivalent was excluded from the analysis of chiasmata. Standard $2 n=40$ males displayed a basically P-D chiasma distribution in autosomal bivalents with a predominance of $\mathrm{D}$ chiasmata (Table 2). Numbers of chiasmata per cell ranged from 19 to 28 with a mean chiasma frequency $( \pm \mathrm{SE})$ of $22.83 \pm 0.31$. Cell mean frequencies of $\mathrm{P}, \mathrm{I}$ and $\mathrm{D}$ chiasmata were, respectively: $5.88 \pm 0.35 ; 2.78 \pm 0.22$ and $14.18 \pm 0.23$. A majority of bivalents was monochiasmate (mean: $14.95 \pm 0.49$ ) and the rest bichiasmate (mean: $4.05 \pm 0.49$ ). Bichiasmate configurations tended to occur in the larger bivalents and most of them (93.5\%) were of the P-D type.

Populations of the John O'Groats race are monomorphic, all individuals sharing the same $2 n=32$ karyotype that includes four homozygous $\mathrm{Rb}$ fusions: $4.10,6.13,9.12$ and 11.14. Chiasmata per cell ranged from 19 to 25 with a cell mean chiasma frequency of $22.28 \pm 0.29$. The difference in cell mean chiasma frequencies between the John O'Groats and standard races is statistically significant $(F=2.59$; d.f. $=1,66$; $P<0.05)$.

The frequencies of P, I and D chiasmata in John O'Groats race individuals were, respectively: $4.37 \pm 0.29$, $2.53 \pm 0.29$ and $15.38 \pm 0.32$. This chiasma distribution is significantly different from that of the $2 n=40$ individuals (contingency $\chi^{2}=11.86$; d.f. $=2 ; P<0.05$ ) (Table 2). However, it is clear that this difference relates to the differential behaviour of the telocentric and

Table 2 Chiasma distribution in male house mice from the John O'Groats-standard hybrid zone. In the cases of $2 n=32$ and hybrid individuals, chiasma patterns are shown separately for telocentric bivalents and Robertsonian configurations. The values in parentheses in the first column correspond to the number of mice studied

\begin{tabular}{lrrc}
\hline & \multicolumn{3}{c}{$\%$ Chiasmata } \\
\cline { 2 - 4 } Karyotype & \multicolumn{1}{c}{$\mathrm{P}$} & $\mathrm{I}$ & $\mathrm{D}$ \\
\hline $2 n=40(7)$ & 27.71 & 14.84 & 57.45 \\
$2 n=32(3)$ & & & \\
$\quad$ Telocentric bivalents & 27.00 & 11.76 & 61.24 \\
$\quad$ Rb bivalents & 7.07 & 9.09 & 83.84 \\
Hybrids (22) & & & \\
$\quad$ Telocentric bivalents & 23.99 & 14.50 & 61.51 \\
$\quad$ Rb bivalents & 5.31 & 9.88 & 84.81 \\
$\quad$ Rb trivalents & 22.39 & 21.15 & 56.46 \\
\hline
\end{tabular}

metacentric bivalents. Chiasma distribution in both groups is notably different: the telocentric bivalents show a typical P-D pattern whereas the metacentrics have a basically distal one (Table 2 ). This difference is statistically highly significant $\left(\chi^{2}=70.75 ; \quad\right.$ d.f. $=2$; $P<0.001)$; furthermore, when chiasma distribution of the telocentric bivalents alone is compared to that of the $2 n=40$ males, both patterns are not significantly different $\left(\chi^{2}=2.13\right.$; d.f. $\left.=2 ; 0.25<P<0.50\right)$.

The difference in chiasma distribution between telocentrics and metacentrics also involves a decrease of chiasma frequency in the latter. Cell mean chiasma frequency of the $2 n=32$ individuals is lower than that of the $2 n=40$ ones (22.28 vs. 22.83$)$ as shown before. However, $27.46 \%$ of the telocentric bivalents of the John O'Groats race are bichiasmate while only $3.70 \%$ of the metacentric arms have two chiasmata in the same race. Thus, mean chiasma frequencies per bivalent arm are 1.28 and 1.04 for telocentrics and metacentrics, respectively.

\section{Chiasma frequency and distribution in males from the John O'Groats-standard hybrid zone}

As indicated above, individuals homozygous for the four John O'Groats race metacentrics predominate in the north-eastern corner of Caithness. Over the rest of Caithness and Sutherland, chromosome arms 4, 6, 9, 10, $11,12,13$ and 14 occur in a polymorphic state which has been interpreted as representing a hybrid zone between the $2 n=32$ and $2 n=40$ races (Searle, 1991; Searle et al., 1993). An analysis of chiasma frequency and distribution was performed in males from several localities within the hybrid zone, showing different homozygous and heterozygous combinations of the four $\mathrm{Rb}$ metacentrics (Table 1). Although cell mean chiasma frequency showed wide inter-individual variation in males from the hybrid zone (20.29-23.75), there is a general tendency for a decrease in chiasma frequency with increase in the number of $\mathrm{Rb}$ configurations (bivalents and trivalents in the case of $\mathrm{Rb}$ homozygosity and heterozygosity, respectively). Thus, $2 n=40$ individuals (no $\mathrm{Rb}$ configurations) have a pooled frequency of 22.83, whereas those with $\mathrm{Rb}$ configurations (bivalents and/or trivalents) have: 22.43 (two Rb configurations), 21.90 (three $\mathrm{Rb}$ configurations) and 21.42 (four $\mathrm{Rb}$ configurations including $2 n=32$ individuals); no individuals with only one configuration were observed; a highly significant negative correlation exists for these mean values $(r=-0.9913 ; t=10.65$; d.f. $=2 ; P<0.01)$. As shown above, in the John O'Groats race, the $\mathrm{Rb}$ bivalents show a differential behaviour with respect to the telocentric bivalents regarding chiasma frequency and distribution. It was expected that the same 
phenomenon would occur in hybrids with various combinations of $\mathrm{Rb}$ bivalents and trivalents, that could account for the decrease in chiasma frequency. The situation is however, more complex.

The telocentric bivalents show the same chiasma distribution as those of the $2 n=40$ and $2 n=32$ individuals (contingency $\chi^{2}=6.56$; d.f. $=4 ; 0.10<P<0.25$ ) (Table 2). The $\mathrm{Rb}$ configurations show, as expected, a differential chiasma pattern but bivalents and trivalents behave in a radically different way. First, all the metacentric bivalents show the same distal chiasma pattern and reduction of chiasma frequency as those of the John O'Groats race regardless of the rest of the karyotype $\left(\chi^{2}=3.32 ;\right.$ d.f. $\left.=2 ; 0.10<P<0.25\right)$ (Table 2); this behaviour is present in all metacentric bivalents of all individuals analysed and seems to be independent of the arm combination involved as the comparison in Table 3 shows for 4.10 and 11.14. The trivalents however, not only show usually higher mean chiasma frequencies than the metacentric bivalents as a per arm comparison demonstrates $(F=23.33$; d.f. $=$ $11834 ; P<0.01$ ), but have a completely different pattern of chiasma distribution in which pronounced increases of $\mathrm{P}$ and I chiasmata occur (Table 4). This difference between $\mathrm{Rb}$ bivalents and trivalents is statistically highly significant $\left(\chi^{2}=188.51 ;\right.$ d.f. $=2 ; P<$ $0.001)$. Furthermore, the increase is highly significant for both $\mathrm{P}(F=142.71$, d.f. $=11,884 ; P<0.01)$ and $\mathrm{I}$ chiasmata $(F=501.90$, d.f. $=11,884, P<0.01)$ when tested independently. In fact, trivalents show an even higher proportion of $\mathrm{P}+\mathrm{I}$ chiasmata than telocentric bivalents (Table 2), although the latter have a significantly higher chiasma frequency per arm than trivalents $(F=38.00 ;$ d.f. $=1,1420 ; P<0.01)$. However, when both types of chiasmata are tested independently, telocentric bivalents have more $\mathrm{P}$ chiasmata than trivalents $(F=18.12$; d.f. $=1,992 ; P<0.01)$ and fewer I chiasmata $(F=8.375 ; \quad$ d.f. $=1, \quad 992 ; \quad P<0.01)$.
Furthermore, trivalent behaviour is independent of the trivalent involved, as the data included in Table 3 show. Relative to telocentric bivalents, $\mathrm{Rb}$ bivalents have a more pronounced reduction of chiasma frequency per arm than trivalents $(F=168.32$; d.f. $=1,2196$, $P<0.01)$ and also significantly less $\mathrm{P}(F=314.27$; d.f. $=11,800 ; P<0.01)$ and $\mathrm{I}$ chiasmata $(F=16.16$; d.f. $=11,800 ; P<0.01)$. It is worth noting that pairing behaviour of both types of $\mathrm{Rb}$ configuration is highly regular as indicated by the very low and similar frequency of chiasma failure: $3.2 \%$ for bivalents and $3.3 \%$ for trivalents.

\section{Discussion}

Robertsonian rearrangements occupy a prominent place in animal cytogenetics because they are commonly observed and easily analysed in cytological preparations (White, 1978; King, 1993). They have been studied as spontaneous mutants, balanced polymorphisms and within hybrid zones or in synthetic hybrids, and have been implicated in chromosomal speciation models (White, 1978; Capanna, 1982; Baker \& Bickham, 1986; Sites \& Moritz, 1987; Redi \& Capanna, 1988; Searle, 1988, 1993; Bidau, 1991; King, 1993; Bidau \& Martí, 1995). Although models vary in a number of details, most assume that the fertility of heterozygous hybrids is reduced relative to homozygotes. Underdominance of the rearrangements is attributed to segregation failure of multiple configurations, and most meiotic studies have been centred in these aspects (Gropp \& Winking, 1981; Redi \& Capanna, 1988; Bidau, 1991, 1996; Mercer et al., 1992; Bidau \& Martí, 1995; Hauffe \& Searle, 1998). However, except for extensive studies on the grasshopper Dichroplus pratensis, a species with a complex Robertsonian system (Bidau, 1990, 1991, 1993, 1996; Mirol \& Bidau, 1992; Bidau \& Martí, 1995), data on chiasma variation are scarce for comparable $\mathrm{Rb}$ systems

Table 3 Frequencies of total (T), proximal (P), interstitial (I) and distal (D) chiasmata in three types of Robertsonian trivalent (III) and two types of Robertsonian bivalent (II) of male house mice from the John O'Groats-standard hybrid zone. The chiasma distributions of the three trivalents do not differ from each other $(G=2.242$; d.f. $=4$; $0.50<P<0.75)$ nor do the chiasma distributions of the two bivalents $(G=0.762$; d.f. $=2 ; 0.50<P<0.75)$. The values in parentheses in the first column correspond to the number of mice studied

\begin{tabular}{|c|c|c|c|c|}
\hline \multirow[b]{2}{*}{ Configuration } & \multicolumn{4}{|c|}{ Chiasmata per trivalent or bivalent } \\
\hline & $\mathrm{T} \pm \mathrm{SE}$ & $\mathrm{P} \pm \mathrm{SE}$ & $\mathrm{I} \pm \mathrm{SE}$ & $\mathrm{D} \pm \mathrm{SE}$ \\
\hline III 9-9.12-12 (1) & $2.15 \pm 0.11$ & $0.45 \pm 0.11$ & $0.50 \pm 0.13$ & $1.20 \pm 0.17$ \\
\hline III 11-11.14-14 (1) & $2.16 \pm 0.09$ & $0.44+0.13$ & $0.28 \pm 0.11$ & $1.44 \pm 0.14$ \\
\hline II 4-4.10-10 (3) & $2.05 \pm 0.08$ & $0.07 \pm 0.03$ & $0.35 \pm 0.07$ & $1.63 \pm 0.08$ \\
\hline
\end{tabular}


Table 4 Frequencies of total (T), proximal (P), interstitial (I), distal (D) and proximal plus interstitial $(\mathrm{P}+\mathrm{I})$ chiasmata per meiotic configuration in male house mice carrying Robertsonian fusions from the John O'Groats-standard hybrid zone

\begin{tabular}{|c|c|c|c|c|c|c|}
\hline \multirow{2}{*}{$\begin{array}{l}\text { Individual } \\
\text { No. }\end{array}$} & \multirow[b]{2}{*}{ Configuration } & \multicolumn{5}{|c|}{ Chiasmata } \\
\hline & & $\mathrm{T}$ & $\mathrm{P}$ & I & $\mathrm{D}$ & $\mathrm{P}+\mathrm{I}$ \\
\hline \multirow[t]{2}{*}{1001} & 2RbII & 2.167 & 0.333 & 0.000 & 1.834 & 0.333 \\
\hline & TII & 1.177 & 0.289 & 0.044 & 0.844 & 0.333 \\
\hline \multirow[t]{2}{*}{1003} & 2RbII & 2.000 & 0.000 & 0.188 & 1.812 & 0.188 \\
\hline & TII & 1.288 & 0.444 & 0.088 & 0.756 & 0.532 \\
\hline \multirow[t]{2}{*}{1004} & 2RbII & 2.000 & 0.250 & 0.000 & 1.750 & 0.250 \\
\hline & TII & 1.198 & 0.366 & 0.166 & 0.666 & 0.532 \\
\hline \multirow[t]{2}{*}{1005} & 3RbII & 2.000 & 0.000 & 0.000 & 2.000 & 0.000 \\
\hline & TII & 1.153 & 0.154 & 0.230 & 0.769 & 0.384 \\
\hline \multirow[t]{2}{*}{1008} & 3RbII & 2.000 & 0.000 & 0.266 & 1.734 & 0.266 \\
\hline & TII & 1.231 & 0.354 & 0.046 & 0.831 & 0.400 \\
\hline \multirow[t]{2}{*}{1009} & 4RbII & 2.139 & 0.278 & 0.139 & 1.722 & 0.417 \\
\hline & TII & 1.252 & 0.293 & 0.141 & 0.818 & 0.434 \\
\hline \multirow[t]{3}{*}{1010} & 3RbII & 2.000 & 0.111 & 0.148 & 1.741 & 0.259 \\
\hline & 1RbIII & 2.000 & 0.000 & 0.444 & 1.556 & 0.444 \\
\hline & TII & 1.213 & 0.253 & 0.253 & 0.707 & 0.506 \\
\hline \multirow[t]{3}{*}{1012} & 1RbII & 2.111 & 0.111 & 0.555 & 1.445 & 0.666 \\
\hline & 2RbIII & 2.222 & 0.611 & 0.333 & 1.278 & 0.944 \\
\hline & TII & 1.162 & 0.282 & 0.145 & 0.735 & 0.427 \\
\hline \multirow[t]{3}{*}{1013} & 2RbII & 2.160 & 0.120 & 0.140 & 1.900 & 0.260 \\
\hline & 1RbIII & 2.160 & 0.440 & 0.280 & 1.440 & 0.720 \\
\hline & TII & 1.134 & 0.246 & 0.223 & 0.665 & 0.469 \\
\hline \multirow[t]{3}{*}{1014} & 2RbII & 2.025 & 0.100 & 0.225 & 1.690 & 0.335 \\
\hline & 1RbIII & 2.300 & 0.600 & 0.200 & 1.500 & 0.800 \\
\hline & TII & 1.266 & 0.392 & 0.212 & 0.662 & 0.604 \\
\hline \multirow[t]{3}{*}{1015} & 2RbII & 2.000 & 0.071 & 0.071 & 1.818 & 0.142 \\
\hline & 2RbIII & 2.357 & 0.571 & 0.500 & 1.286 & 1.071 \\
\hline & TII & 1.227 & 0.288 & 0.136 & 0.803 & 0.424 \\
\hline \multirow[t]{3}{*}{1016} & 1RbII & 2.064 & 0.064 & 0.258 & 1.742 & 0.322 \\
\hline & 2RbIII & 2.048 & 0.338 & 0.532 & 1.178 & 0.870 \\
\hline & TII & 1.215 & 0.327 & 0.173 & 0.715 & 0.500 \\
\hline \multirow[t]{2}{*}{1017} & 2RbII & 2.000 & 0.050 & 0.250 & 1.700 & 0.300 \\
\hline & TII & 1.123 & 0.263 & 0.130 & 0.730 & 0.393 \\
\hline \multirow[t]{3}{*}{1018} & 1RbII & 2.000 & 0.050 & 0.250 & 1.700 & 0.300 \\
\hline & 2RbIII & 2.050 & 0.300 & 0.625 & 1.025 & 0.925 \\
\hline & TII & 1.196 & 0.242 & 0.235 & 0.719 & 0.477 \\
\hline \multirow[t]{3}{*}{1019} & 2RbII & 2.100 & 0.125 & 0.125 & 1.850 & 0.250 \\
\hline & 1RbIII & 2.150 & 0.650 & 0.450 & 1.050 & 1.100 \\
\hline & TII & 1.231 & 0.304 & 0.173 & 0.754 & 0.477 \\
\hline \multirow[t]{2}{*}{1020} & 3RbII & 2.042 & 0.083 & 0.208 & 1.751 & 0.291 \\
\hline & TII & 1.232 & 0.308 & 0.212 & 0.712 & 0.520 \\
\hline \multirow[t]{3}{*}{1023} & 2RbII & 2.055 & 0.055 & 0.388 & 1.612 & 0.443 \\
\hline & 2RbIII & 2.111 & 0.500 & 0.722 & 0.889 & 1.222 \\
\hline & TII & 1.104 & 0.143 & 0.130 & 0.831 & 0.273 \\
\hline \multirow[t]{2}{*}{1024} & 2RbII & 2.075 & 0.075 & 0.100 & 1.900 & 0.175 \\
\hline & TII & 1.227 & 0.350 & 0.107 & 0.770 & 0.457 \\
\hline
\end{tabular}




\begin{tabular}{llccccc}
\hline \multirow{2}{*}{$\begin{array}{l}\text { Individual } \\
\text { No. }\end{array}$} & Configuration & $\mathrm{T}$ & $\mathrm{P}$ & $\mathrm{I}$ & $\mathrm{D}$ & $\mathrm{P}+\mathrm{I}$ \\
\cline { 3 - 7 } 1025 & 3RbII & 2.074 & 0.148 & 0.222 & 1.704 & 0.370 \\
& 1 RbIII & 2.222 & 0.444 & 0.555 & 1.223 & $\mathbf{0 . 9 9 9}$ \\
& TII & 1.112 & 0.172 & 0.263 & 0.677 & 0.435 \\
1026 & 2RbII & 2.200 & 0.100 & 0.100 & 2.000 & 0.200 \\
& TII & 1.187 & 0.267 & 0.173 & 0.747 & 0.440 \\
1027 & 1RbII & 2.000 & 0.050 & 0.400 & 1.550 & 0.450 \\
& 2RbIII & 2.300 & 0.800 & 0.375 & 1.125 & $\mathbf{1 . 1 7 5}$ \\
& TII & 1.165 & 0.223 & 0.177 & 0.765 & 0.400 \\
1028 & 2RbII & 2.000 & 0.150 & 0.150 & 1.700 & 0.300 \\
& 1RbIII & 2.150 & 0.450 & 0.500 & 1.000 & $\mathbf{0 . 9 5 0}$ \\
& TII & 1.203 & 0.273 & 0.165 & 0.765 & 0.438 \\
1035 & 4RbII & 2.025 & 0.150 & 0.125 & 1.750 & 0.275 \\
& TII & 1.210 & 0.255 & 0.191 & 0.764 & 0.446 \\
1036 & 4RbII & 1.963 & 0.075 & 0.263 & 1.625 & 0.330 \\
& TII & 1.391 & 0.450 & 0.127 & 0.814 & 0.577 \\
\hline
\end{tabular}

Table 4 (Continued)

RbII, Robertsonian bivalent; RbIII, Robertsonian trivalent; TII, telocentric bivalent.

Frequencies of $\mathrm{P}+\mathrm{I}$ chiasmata of trivalents are shown in bold type.

such as Mus musculus domesticus and the common shrew (Sorex araneus) (Searle, 1986; Wallace et al., 1992).

Detailed analysis is relevant because number and position of chiasmata affect the symmetry of heterozygous meiotic configurations which in turn can affect metaphase I orientation and anaphase I disjunction (Sybenga, 1975; Mirol \& Bidau, 1992; Bidau \& Martí, 1995; Bidau, 1996). This is pertinent, since a common effect of chromosomal rearrangement in well studied groups such as grasshoppers is the repatterning of chiasmata in the chromosomes involved (Bidau \& Martí, 1995), but almost no information exists on mammals. Repatterning of chiasmata could explain the adaptive value or the underdominance of the rearrangements by creating conditions for supergene formation or disruption, respectively (Bidau \& Martí, 1995; Bidau, 1996).

Although many studies have analysed recombination and chiasmata in M. musculus, either because of their intrinsic genetic interest or in relation to other phenomena, most have been performed on laboratory strains (Searle et al., 1970; Kyslikova \& Forejt, 1972; Polani, 1972; Berry et al., 1973; Lyon, 1976; Speed, 1977; Maudlin \& Evans, 1980; Nijhoff \& de Boer, 1981; Gorlov et al., 1992; Lawrie et al., 1995; Nachman \& Churchill, 1996). However, in several cases detailed studies of male and female chiasma distribution are available (Polani, 1972; Speed, 1977; Nijhoff \& de Boer, 1981; Lawrie et al., 1995).
Quantitative chiasma studies in feral $\mathrm{Rb}$ mice are almost nonexistent (Wallace et al., 1992). The John O'Groats-standard hybrid zone was formed through the reproductive interaction of the $2 n=32$ race from John O'Groats with the widespread $2 n=40$ standard race and is a clear example of a staggered hybrid zone that results in zonal populations where most individuals are homozygous for some, but not all, of the metacentrics that characterize the metacentric race (Searle, 1991, 1993; Searle et al., 1993). Our results indicate that three different effects of the four $\mathrm{Rb}$ fusions on chiasmata are present in these mice. First, increasing numbers of $\mathrm{Rb}$ configurations are significantly negatively correlated with cell mean chiasma frequency; this agrees with the case of $D$. pratensis, in which populations with increasing frequencies and numbers of $\mathrm{Rb}$ fusions show decreasing mean populational chiasma frequencies (Bidau, 1990); the same effect is observed within populations. Second, as in D. pratensis, reduction of chiasma frequency is due to an intrachromosomal effect of the fusions accompanied by a redistribution of chiasmata (Bidau, 1990). This effect has not been previously reported in feral mice (Gropp \& Winking, 1981). Telocentric bivalents are unaffected and retain the same chiasma characteristics in the presence or absence of the $\mathrm{Rb}$ chromosomes; indeed, the $2 n=40$ males studied by us show mean chiasma frequencies that fall within the range of chiasma frequencies of standard laboratory mice (Searle et al., 1970; Kyslikova \& Forejt, 
1972; Polani, 1972; Berry et al., 1973; Speed, 1977; Maudlin \& Evans, 1980; Nijhoff \& de Boer, 1981; Gorlov et al., 1992; Lawrie et al., 1995); the chiasma distribution that we observed in telocentric bivalents is likewise similar to that previously found in laboratory mice (Maudlin \& Evans, 1980; Lawrie et al., 1995).

However, in $\mathrm{Rb}$ mice from the John O'Groatsstandard hybrid zone, there are differences between homozygous and heterozygous configurations. Whereas in $D$. pratensis, both $\mathrm{Rb}$ bivalents and trivalents show a displacement of chiasmata towards distal ends of chromosome arms in both sexes (Bidau \& Martí, 1995), in Caithness mice, only Rb bivalents show such repatterning, which is independent of the $\mathrm{Rb}$ chromosomes involved (Table 3). All trivalents show the opposite behaviour: a significant increase of $\mathrm{P}$ and $\mathrm{I}$ chiasmata.

There is evidence that these effects of $\mathrm{Rb}$ fusions could be more widespread in the house mouse. (1) Polani (1972) studied laboratory mice homozygous for a $6.15 \mathrm{Rb}$ fusion and found a strong tendency to distal localization of chiasmata in the short arm, although chiasma frequency did not seem to be affected. (2) Maudlin \& Evans (1980) studied chiasma formation in oocytes of laboratory mice homozygous for the $\mathrm{Rb}(5.15) 3 \mathrm{Bnr}$ translocation and found a lack of interference across the centromere regarding the number of chiasmata, but a strong tendency to distal localization in both arms and an elimination of chiasmata around the centromere. (3) Recently, Dumas \& Britton-Davidian (2000) reported what seems to be a similar situation to ours in two races $(2 n=40$ and $2 n=22)$ of $M . m$. domesticus and their hybrids in Tunisia. (4) These opposite effects are not restricted to the Western European house mouse. The same differential chiasma formation occurs in $\mathrm{Rb}$ homozygotes and heterozygotes of the Ctenomys perrensi species complex (Caviomorpha, Ctenomyidae) from Argentina (C. Lanzone, personal communication) and in the South American marsh rat Holochilus brasiliensis (Nachman, 1992).

Why does this different behaviour of $\mathrm{Rb}$ bivalents and trivalents occur? The results suggest that different mechanical rules operate for chiasma formation in house mice relative to $D$. pratensis. In $D$. pratensis, a simple model explains the parallel chiasma repatterning of both configurations: since in grasshoppers pairing usually starts at chromosome ends attached to the nuclear envelope and assuming that chiasmata are formed more readily in regions that pair first (Jones, 1987), a Rb fusion (homozygous or heterozygous) instantly reduces the early pairing ends from four to two: the distal ones (Martí \& Bidau, 2000; Bidau, 1993; Bidau \& Martí, 1995). In house mice this is not applicable. First, trivalents and bivalents behave in opposite ways; second, recent observations do not suggest that telomeric sequences initiate synapsis in the house mouse (Moens et al., 1995).

According to these effects on chiasma formation, what are the possible evolutionary influences of $\mathrm{Rb}$ fusions in natural populations of house mice? They could exert a form of recombination control. Lyon (1976) proposed that recombination was not random in $M$. musculus, based on the analysis of the then known genetic map, since genetic markers were not evenly distributed along mouse chromosomes, but clustered. Lyon suggested that this could be a direct reflection of chiasma localization. This hypothesis was indirectly supported by the patterns of chiasma location found in mouse bivalents, and was demonstrated by Nachman \& Churchill (1996), who analysed the distribution of markers along the M. musculus microsatellite map. Thus, changes in chiasma frequency in Rb homozygotes and heterozygotes of $M . m$. domesticus, as we observed, may change the recombination frequencies of different parts of the genome, for example by the creation of relatively recombination-free zones in $\mathrm{Rb}$ homozygotes (in the proximal and interstitial regions of the metacentrics).

With respect to the John O'Groats-standard hybrid zone, the distribution of chiasmata in hybrids influences the gene flow across the zone. The presence of chiasmata near the centromere in $\mathrm{Rb}$ heterozygotes enhances the possibility of gene flow for loci along the whole of the $\mathrm{Rb}$ chromosome. This reduces the opportunity for genetic differentiation of the John O'Groats and standard races while in contact (see Searle, 1993).

In experiments in which wild $\mathrm{Rb}$ metacentrics were introduced into standard laboratory mouse genomes, some metacentrics suppressed pericentromeric genetic recombination in heterozygous individuals (Cattanach, 1978; Davisson \& Akeson, 1993). These cases were attributed by Davisson \& Akeson (1993) to delayed pairing of pericentromeric areas of trivalents, and would seem to contradict our findings. However, there are many $\mathrm{Rb}$ metacentrics that do not suppress pericentromeric recombination (Davisson \& Akeson, 1993), and even the cases of true suppression could be due to interactions between the genetic background and the metacentric chromosomes peculiar to certain lines of laboratory mice. The situation is clearly different from that of the wild populations studied in this paper in which the $\mathrm{Rb}$ polymorphisms arose from a past event of hybridization and underwent many generations of natural selection.

The occurrence of I and P chiasmata in Robertsonian heterozygous mice is interesting in other respects. First, in relation to the low anaphase I nondisjunction suffered by such individuals (only $2.7 \%$ per heterozygous 
configuration; Wallace et al., 1992). Distal location of chiasmata is considered important for correct segregation (Sybenga, 1975). Clearly, our results cast doubt on this. Secondly, such a distribution of chiasmata would fail to protect from recombination any supergene formed by Robertsonian fusion in the metacentric race.

\section{Acknowledgements}

The authors wish to acknowledge the support of CONICET, Argentina (C.J.B. and M.D.G.) and the Natural Environment Research Council, U.K. (J.B.S. and C.P.). They are also indebted to Dr Bridget M. N. Wallace (Birmingham) and two anonymous reviewers for critical reading of the manuscript.

\section{References}

BAKER, R. J. AND BICKHAM, J. W. 1986. Speciation by mononbrachial centric fusions. Proc. Nat. Acad. Sci. U.S.A., 83, $8245-8248$.

BARTON, N. H. AND HEWITT, G. M. 1981. Hybrid zones and speciation. In: Atchley, M. R. and Woodruff, D. S. (eds) Evolution and Speciation, pp. 109-145. Cambridge University Press, Cambridge.

BERRY, R. J., BEECHEY, C. V. AND SEARLE, A. G. 1973. Cytogenetic radiosensitivity and chiasma frequency in wild and laboratory mice. Mutat. Res., 19, 129-131.

BIDAU, C. J. 1990. The complex Robertsonian system of Dichroplus pratensis (Melanoplinae, Acrididae). II. Effects of the fusions polymorphisms on chiasma frequency and distribution. Heredity, 64, 145-159.

BIDAU, C. J. 1991. Multivalents resulting from monobrachial homologies within a hybrid zone in Dichroplus pratensis (Acrididae): meiotic orientation and segregation. Heredity, 66, 219-232.

BIDAU, C. J. 1993. Causes of chiasma repatterning due to centric fusions. Brazil J. Genet., 16, 283-296.

BIDAU, C. J. 1996. Chiasma repatterning in hybrids between chromosomal races of the grasshopper Dichroplus pratensis (Melanoplinae, Acrididae). Cytobios, 85, 91-110.

BIDAU, C. J. AND MARTí, D. A. 1995. Male and female meiosis in Robertsonian heterozygotes of Dichroplus pratensis (Acrididae). In: Brandham, P. E. and Bennett, M. D. (eds) Kew Chromosome Conference IV, pp. 381-396. Royal Botanic Gardens, Kew.

BIDAU, C. J. AND TOSTO, D. S. 1991. Distribution of chromosome frequencies within a hybrid zone of Dichroplus pratensis (Melanoplinae, Acrididae). Heredity, 67, 299-306.

CAPANNA, E. 1982. Robertsonian numerical variation in animal speciation: Mus musculus, an emblematic model. In: Barigozzi, C. (ed.) Mechanisms of Speciation, pp. 155-177. Alan R. Liss, New York.

CATTANACH, B. M. 1978. Crossover suppression in mice heterozygous for tobacco mouse metacentrics. Cytogenet. Cell Genet., 20, 264-281.
DAVISSON, M. T. AND AKESON, E. C. 1993. Recombination suppression by heterozygous Robertsonian chromosomes in the mouse. Genetics, 133, 649-667.

DUMAS, D. AND BRITTON-DAVIDIAN, J. 2000. Does heterozygosity for chromosomal rearrangements affect recombination patterns? Abstracts. Hybridisation, Phylogeography and Speciation: a Discussion Meeting. Aussois, France.

EVANS, E. P., BRECKON, G. AND FORD, C. E. 1964. An air-drying method for meiotic preparations for mammalian testes. Cytogenetics, 33, 289-294.

FORD, C. E. 1966. The use of chromosome markers. In: Micklem, H. S. and Loutit, J. F. (eds) Tissue Grafting and Radiation, pp. 197-206. Academic Press, New York.

GORLOV, I., SCHULER, L., BUNGER, L. AND BORODIN, P. 1992. Chiasma frequency in strains of mice selected for litter size or high body weight. Theor. Appl. Genet., 84, 640-642.

GROPP, A. AND WINKING, H. 1981. Robertsonian translocations: Cytology, meiosis, segregation patterns and biological consequences of heterozygosity. Symp. Zool. Soc. Lond., 47, 141-181.

HAuffe, H. C. AND SEARLe, J. B. 1998. Chromosomal heterozygosity and fertility in house mice (Mus musculus domesticus) from Northern Italy. Genetics, 150, 1143-1154.

JOHN, B. 1983. The role of chromosome change in the evolution of Orthopteroid insects. In: Sharma, A. K. and Sharma, A. S. (eds) Chromosomes in the Evolution of Eukaryotic Groups. I, pp. 1-110. CRC Press, Boca Raton.

JoHN, B. 1990. Meiosis. Cambridge University Press, Cambridge.

JONES, G. H. 1987. Chiasmata. In: Moens, P. B. (ed.) Meiosis, pp. 213-244. Academic Press, Orlando, FL.

JONES, K. 1990. Robertsonian changes in allies of Zebrina (Commelinaceae). Pl. Syst. Evol., 172, 263-271.

KING, M. 1993. Species Evolution. The Role of Chromosome Change. Cambridge University Press, Cambridge.

KYSLIKOVA, L. AND FOREJT, J. 1972. Chiasma frequency in three inbred strains of mice. Folia Biol., 18, 216-218.

LAWRIE, N. M., TEASE, C. AND HUltÉN, M. 1995. Chiasma frequency, distribution and interference maps of mouse chromosomes. Chromosoma, 140, 308-313.

LYON, M. F. 1976. Distribution of crossing-over in mouse chromosomes. Genet. Res., 28, 291-299.

MARTí, D. A. AND BIDAU, C. J. 2000. Synapsis in Robertsonian heterozygotes and homozygotes of Dichroplus pratensis (Melanoplinae, Acrididae) and its relationship with crossing-over patterns. Hereditas, in press:.

MAUdLIN, I. AND EVANS, E. P. 1980. Chiasma distribution in mouse oocytes during diakinesis. Chromosoma, 80, 49-56.

MERCER, S. J., WALlaCe, B. M. N. AND SEARLE, J. B. 1992. Male common shrews (Sorex araneus) with long meiotic chain configurations can be fertile: implications for chromosomal models of speciation. Cytogenet. Cell Genet., 60, 68-73.

MIROL, P. M. AND BIDAU, C. J. 1992. Proximal chiasmata induce non-disjunctional orientation of Robertsonian trivalents in a grasshopper. Heredity, 69, 268-278.

MOENS, P. B. AND SPYROPOULOS, B. 1995. Immunocytology of chiasmata and chromosomal disjunction at mouse meiosis. Chromosoma, 104, 175-182. 
MOENS, P. B., HENG, H. H. Q., PEARLMAN, R. E., ROSONINA, E. ET AL. 1995. Meiotic chromosomes visualized with antibodies and DNA probes. In: Brandham, P. E. and Bennett, M. D. (eds) Kew Chromosome Conference IV, pp. 375-379. Royal Botanic Gardens, Kew.

NACHMAN, M. W. 1992. Meiotic studies of Robertsonian polymorphisms in the South American marsh rats, Holochilus brasiliensis. Cytogenet. Cell Genet., 61, 7-24.

NACHMAN, M. W. AND CHURCHILL, G. A. 1996. Heterogeneity in rates of recombination across the mouse genome. Genetics, 142, 537-548.

NACHMAN, M. W. AND SEARLE, J. B. 1995. Why is the mouse karyotype so variable? Trends Ecol. Evol., 10, 397-402.

NIJHOFF, J. H. AND DE BOER, P. 1981. Spontaneous meiotic nondisjunction in mammals. A study evaluating the various experimental approaches. Genetica, 56, 99-121.

POLANI, P. E. 1972. Centromere localization at meiosis and the position of chiasmata in the male and female mouse. Chromosoma, 36, 343-374.

REDI, C. A. AND CAPANNA, E. 1988. Robertsonian heterozygotes in the house mouse and the fate of their germ cells. In: Daniel, A. (ed.) The Cytogenetics of Mammalian Autosomal Rearrangements, pp. 315-359. Alan R. Liss, New York.

SEABRIGHT, M. 1972. A rapid banding technique for human chromosomes. Lancet, 2, 971-972.

SEARLE, J. B. 1986. Meiotic studies of Robertsonian heterozygotes from natural populations of the common shrew, Sorex araneus L. Cytogenet. Cell. Genet., 41, 154-162.

SEARLE, J. B. 1988. Selection and Robertsonian variation in nature: The case of the common shrew. In: Daniel, A. (ed.)
The Cytogenetics of Mammalian Autosomal Rearrangements, pp. 507-532. Alan R. Liss, New York.

SEARLE, J. B. 1991. A hybrid zone comprising staggered chromosomal clines in the house mouse (Mus musculus domesticus). Proc. R. Soc. B, 246, 47-52.

SEARLE, J. B. 1993. Chromosomal hybrid zones in eutherian mammals. In: Harrison, R. G. (ed.) Hybrid Zones and the Evolutionary Process, pp. 507-532. Oxford University Press, Oxford.

SEARLE, A. G., BERRY, R. J. AND BEECHEY, C. v. 1970. Cytogenetic radiosensitivity and chiasma frequency in wild-living male mice. Mutat. Res., 9, 137-140.

SEARle, J. B., NAVARro, Y. N. AND GANEM, G. 1993. Further studies of a staggered hybrid zone in Mus musculus domesticus (the house mouse). Heredity, 71, 523-531.

SITES, J. W. AND MORITZ, C. 1987. Chromosomal evolution and speciation revisited. Syst. Zool., 36, 153-174.

SPEED, R. M. 1977. The effects of ageing on the meiotic chromosomes of male and female mice. Chromosoma, 64, 241-254.

SUMNER, A. T. 1972. A simple technique for demonstrating centromeric heterochromatin. Exp. Cell Res., 75, 304-306.

SYBENGA, J. 1975. Meiotic Configurations. Springer Verlag, Berlin.

WAllace, B. M. N., SEARle, J. B. AND Everett, C. A. 1992. Studies on meiosis and gametogenesis in wild house mice (Mus musculus domesticus): Male 'simple' heterozygotes and homozygotes from a chromosomal hybrid zone. Cytogenet. Cell Genet., 61, 211-220.

White, M. J. D. 1978. Modes of Speciation. W. H. Freeman, San Francisco. 